\title{
Modelling Petroleum Product Prices and the Nigerian Economy
}

\author{
Amagoh, Maureen N,; Odoh, Chijioke M \& Okuh, Benjamin A. \\ Department of Mathematics/Statistics, \\ Delta State Polytechnic Ogwashi-uku, Delta State of Nigeria
}

\begin{abstract}
On January $1^{\text {st }}$ 2012, Nigerians were greeted with removal of petroleum fuel subsidy which resulted in increase on pump prices of petroleum product. Some arguments have it that it will be good for the economy while other argued that it will not favour the average Nigerian, especially those on grassroots. In January 2014 similar speculation on total removal of subsidy on all petroleum products was still on leading to brief scarcity in some areas. a multivariate study of the implications of these prices change on some economic variables reveals that PMS has significant impact on all economic variable studied. The AGO has significant impact on only GDP and Per capita GDP while DPK only has significant impact on GDP per capita. it is there for recommended that only the the removal of PMS subsidy will be good for the Nigerian economy as increase in the price of other products studied will be detrimental to the economy.
\end{abstract}

Keyword: PMS, AGO, DPK, Nigerian Economy, GDP, External Debt, Foreign reserve

\section{Introduction}

Oil products are basically used in industries for production of goods and services and they are also used domestically for personal consumption.. The oil industry is very important to the Nigerian economy. It provides among other things the greatest part of the foreign exchange earnings and total revenue needed for socio-economic and political development of Nigeria. The bulk of Nigerian crude oil is sold unrefined and when refined, the products range from petrol to heavy liquids for road tarring. Government has been the custodian of petroleum and its products in Nigeria[1].

According to Ghalayini[2], crude oil has become one of the main indicators of economic activity worldwide, due to its outstanding importance in the supply of the world's energy demands. A large body of research suggests that oil price fluctuations have considerable consequences on economic activity.

According to Onyemaechi[3], Oil prices are always debatable and remain an important variable in determining the economic activity of any country, thus the size of oil prices increase depends on the share of the cost of oil in overall GDP, the degree of dependence on consumption of oil domestically and dependence on alternative sources of fuel. As Aliyu[4] argued that an oil price increase, all things being equal, should be considered positive in oil exporting countries and negative in oil importing countries, while the reverse should be expected when the oil price decreases.

\section{Statement Of Problem}

On January $1^{\text {st }} 2012$, Nigerians were greeted with removal of petroleum fuel subsidy which resulted in increase on pump prices of petroleum product. some arguments have it that it will be good for the economy while other argued that it will not favour the average Nigerian, especially those on grassroots.

Again, the single most important issue confronting a growing number of world economies today is the price of oil and its attendant consequences on economic output. Oil plays a significant role in the Nigerian economy not only as the largest contributor in terms of total government revenue but also as the overall contributor in her exports composition [5].

Several studies have investigated the effect of oil price shocks on levels of gross domestic product. Some of these studies include: the effect of crude oil prices on real GDP, the real interest rate, government spending, real government revenues, the real stock price, the real effective exchange rate, the real crude oil prices and inflation rate in India [6], effect of crude oil price on exchange rate[7], effect of PMS price on inflation rate in Nigeria[1], effects of increasing oil prices on the manufacturing sector of Nigeria[7].

Majority of these researches where not conducted in Nigeria and where it was conducted, the core areas of the economy where overlooked. It was already projected and estimated globally that the oil demand is expected to increase ninety eight million barrels/ day in next four year (2015) and 118 million barrels per day during next twenty years (in 2030)[6]

This study is necessary at this point since the demand for petroleum product increase is imminent as stated by Sharma, Singh and Gupta[6]Thus the study will help to predict the Nigerian economy given any petroleum price change at the local market. 


\section{PURPOSE OF THE STUDY}

The main objective of this study is to determine the impact of petroleum product prices (Premium Motor Spirit (PMS), Dual Purpose Kerosene (DPK) and Automotive Gas Oil (AGO)) on some economic variables, interest also is to determine the overall contribution of petroleum product prices on the Nigerian economy

\section{SOURCES OF DATA}

The data used for this study were sourced from the Central Bank of Nigeria bulletin, Petroleum Product Pricing Regulatory Agency (PPPRA) pricing template, National Bureau of Statistics Bulletin and United Nations online data base.

\section{SIGNIFICANCE OF THE STUDY}

This study is significant in that it will fit a model that predicts the Nigerian economy given petroleum product prices. This model will be useful in planning the Nigerian economy by channeling the revenue generated from petroleum to those areas that the impact of the petroleum revenue has not been felt. This research will be a good resource in planning how to utilize the excess revenue that will result in the imminent increase in the demand for petroleum products as a result of population explosion and technological breakthrough.

\section{ECONOMIC VARIABLES CONSIDERED}

\section{Gross Domestic Product (USD)}

GDP at purchaser's prices is the sum of gross value added by all resident producers in the economy plus any product taxes and minus any subsidies not included in the value of the products. It is calculated without making deductions for depreciation of fabricated assets or for depletion and degradation of natural resources. Data are in constant 2000 U.S. dollars. Dollar figures for GDP are converted from domestic currencies using 2000 official exchange rates. For a few countries where the official exchange rate does not reflect the rate effectively applied to actual foreign exchange transactions, an alternative conversion factor is used.

\section{Total Reserve (USD)}

Total reserves comprise holdings of monetary gold, special drawing rights, reserves of IMF members held by the IMF, and holdings of foreign exchange under the control of monetary authorities. The gold component of these reserves is valued at year-end (December 31) London prices. Data are in current U.S. dollars.

\section{External Debt (USD)}

Total external debt is debt owed to nonresidents repayable in foreign currency, goods, or services. Total external debt is the sum of public, publicly guaranteed, and private nonguaranteed long-term debt, use of IMF credit, and short-term debt. Short-term debt includes all debt having an original maturity of one year or less and interest in arrears on long-term debt. Data are in current U.S. dollars.

\section{Gross National Expenditure 2000 Constant}

Gross national expenditure (formerly domestic absorption) is the sum of household final consumption expenditure (formerly private consumption), general government final consumption expenditure (formerly general government consumption), and gross capital formation (formerly gross domestic investment). Data are in constant 2000 U.S. dollars.

\section{5 . GDP per Capita 2000 Constant}

GDP per capita is gross domestic product divided by midyear population. GDP is the sum of gross value added by all resident producers in the economy plus any product taxes and minus any subsidies not included in the value of the products. It is calculated without making deductions for depreciation of fabricated assets or for depletion and degradation of natural resources. Data are in constant U.S. dollars.

\section{Literature Review}

Price of oil products is derived from crude oil prices and it therefore follows that prices of petroleum products should trail crude oil prices. For socio-political reasons, government of both oil producing and consuming countries should invariably intervene in the market to influence products price determination. But in the actual fact, the extent of intervention depends on the specific needs of the country and the level of endowment of the products in question. Trailing oil products prices with crude oil prices has revealed that, 
crude oil cost is not the only cost incurred in supply and distribution of petroleum products. Other costs include refining, storing, transporting and distributing, the author asserted[6]

Onwuka, Chiekezie \& Igweze[7] asserted that the causes of price instability is attributed to scarcity caused by refinery maintenance and rehabilitation problem, low capacity utilization, supply, and demand inequality. The political change that Nigeria went through, which turned over the administration and endured a lingering economic down turn is enough reason to cause price instability of oil products in Nigeria. The author opined that trailing oil products prices down to crude oil prices has revealed that the instability in the prices of oil products was due to cost of refining, storing, transporting distributing and inefficiencies in the process.

It was also argued that the dominance of petroleum in Nigerian economy has led to instability in the economy, which as a result makes price instability of oil products to be more prevalent in Nigeria than other countries, while observing that smuggling is attractive and profitable due to price differential. This act of smuggling oil products from Nigeria to her neighboring countries is one of the factors which made price instability of oil products to be prevalent in Nigeria [7].

Ayadi [8] stated that the single most important issue confronting a growing number of world economies today is the price of oil and its attendant consequences on economic output. He notes that several studies have investigated the effect of oil price shocks on levels of gross domestic product. He focused his paper primarily on the relationship between oil price changes and economic development via industrial production. A vector auto regression model was employed on some macroeconomic variables from 1980 through 2004. The results indicate that oil price changes affect real exchange rates, which, in turn, affect industrial production. However, this indirect effect of oil prices on industrial production is not statistically significant. Therefore, the implication of the results presented in this paper is that an increase in oil prices does not lead to an increase in industrial production in Nigeria.

Farzanegan and Markwardt [9] stated that due to the high dependence on oil revenues, oil price fluctuations had a special impact on the Iranian economy. Unexpectedly, the authors noted that they could not identify a significant impact of oil price fluctuation on real government expenditures. Furthermore, the response of inflation to any kind of oil price shocks is significant and positive.

Olomola and Adejumo[10] examine the effect of oil price shock on output, inflation, the real exchange rate and the money supply in Nigeria using quarterly data from 1970 to 2003 . Their findings were contrary to previous empirical findings in other countries; oil price shock does not affect output and inflation in Nigeria. However, oil price shocks did significantly influence the real exchange rates. The implication was that a high real oil price gave rise to wealth effect that appreciated the real exchange rate

Olusegun [11] investigated the impacts of oil price shocks on the macroeconomic performance in Nigeria using Vector Autoregression (VAR) approach. Forecast error variance decomposition is estimated using 7 key Nigerian macroeconomic variables, which are; real gross domestic product, consumer price index, real oil revenue, real money supply, real government recurrent expenditure, real government capital expenditure and real oil price. An annual data between the periods 1970-2005 were employed. The Johansen co integration test identified at least four cointegrating vectors among the variables. The forecast error variance decomposition estimated from the VAR model shows that oil price shocks significantly contribute to the variability of oil revenue and output. On the other hand, the result reveals that oil price shock does not have substantial effects on money supply, price level and government expenditure in Nigeria over the period covered by the study. This is evident, as its contributions to the variability of these variables are very minimal. The study again reveals that the variability in the price level, apart from its own shock, is explained substantially by output and money supply shocks. Also, apart from its own shock, the variability in money supply is also explained by price level and output. This finding confirms, therefore, that oil price shock may not be necessarily inflationary especially, in the case of an open developing economy like Nigeria. The policy implication of this is that fiscal policy can be used more effectively to stabilise the domestic economy after an oil shock

Kilian (2008) used a newly developed measure of global real economic activity, he proposes structural decomposition of the real price of crude oil in four components: oil supply shocks driven by political events in OPEC countries; other oil supply shocks; aggregate shocks to the demand for industrial commodities; and demand shocks that are specific to the crude oil market. The latter shock is designed to capture shifts in the price of oil driven by higher precautionary demand associated with concerns about the availability of future oil supplies. He quantifies the magnitude and timing of these shocks, their dynamic effects on the real price of oil and their relative importance in determining the real price of oil during 1975-2005. The analysis also sheds light on the origins of the major oil price shocks since 1979. Distinguishing between the sources of higher oil prices is shown to be crucial for assessing the effect of higher oil prices on U.S. real GDP and CPI inflation. It is shown that policies aimed at dealing with higher oil prices must take careful account of the origins of higher oil prices. He also quantifies the extent to which the macroeconomic performance of the U.S. since the mid-1970s has been determined by the external economic shocks driving the real price of oil as opposed to domestic economic factors and policies. 
Aliyu[4] assessed the impact of oil price shock and real exchange rate volatility on real economic growth in Nigeria on the basis of quarterly data from 1986Q1 to 2007Q4. The empirical analysis started by analyzing the time series properties of the data which is followed by examining the nature of causality among the variables. Furthermore, the Johansen VAR-based cointegration technique was applied to examine the sensitivity of real economic growth to changes in oil prices and real exchange rate volatility in the long-run while the short run dynamics was checked using a vector error correction model. Results from ADF and PP tests show evidence of unit root in the data and Granger pairwise causality test revealed unidirectional causality from oil prices to real GDP and bidirectional causality from real exchange rate to real GDP and vice versa. His findings showed that oil price shock and appreciation in the level of exchange rate made positive impact on real economic growth in Nigeria. He recommended greater diversification of the economy through investment in key productive sectors of the economy to guard against the vicissitude of oil price shock and exchange rate volatility.

Farzanegan and Markwardt[9] stated that due to the high dependence on oil revenues, oil price fluctuations had a special impact on the Iranian economy. By applying a VAR approach, they analyzed the dynamic relationship between asymmetric oil price shocks and major macroeconomic variables in Iran. Contrary to previous empirical findings for oil net importing developed countries, oil price increases (decreases) have a significant positive (negative) impact on industrial output. Unexpectedly, the authors noted that they cannot identify a significant impact of oil price fluctuation on real government expenditures. The response of real imports and the real effective exchange rate to asymmetric oil price shocks are significant. Furthermore, the response of inflation to any kind of oil price shocks is significant and positive

Olomola and Adejumo[10] examine the effect of oil price shock on output, inflation, the real exchange rate and the money supply in Nigeria using quarterly data from 1970 to 2003 . The VAR method was employed to analyze the data. Their findings were contrary to previous empirical findings in other countries; oil price shock does not affect output and inflation in Nigeria. However, oil price shocks did significantly influence the real exchange rates. The implication was that a high real oil price gave rise to wealth effect that appreciated the real exchange rate.

\section{Research Methodology}

The multivariate regression analysis was used to model the relationship between petroleum product prices and the Nigerian economy. Interest here is in fitting the model of Nigerian economic variables on the petroleum product prices and testing the significance of the variables. The data set used is from 1987 to 2011 , this is large enough to capture current economic trends as well international oil market realities. Again the petroleum product prices fluctuation in Nigeria were quite visible within this period. The SPSS general linear (Multivariate options) was used to model the variables. The large amount of data necessitated the logarithmic transformation in order to reduce the data to a manageable size.

\section{Method of Data Analysis}

Given that

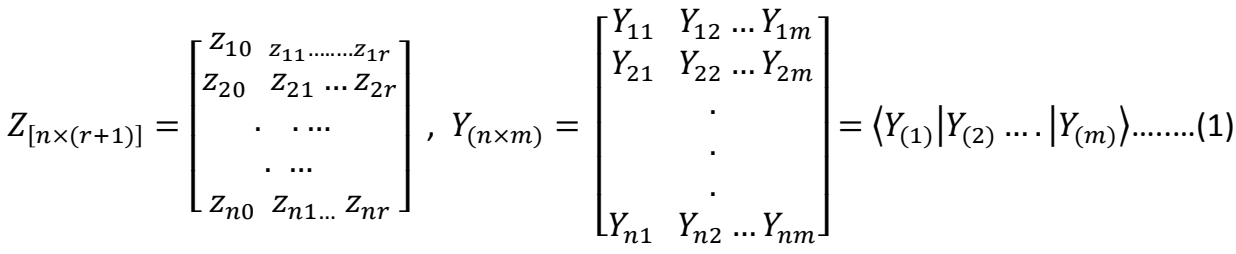

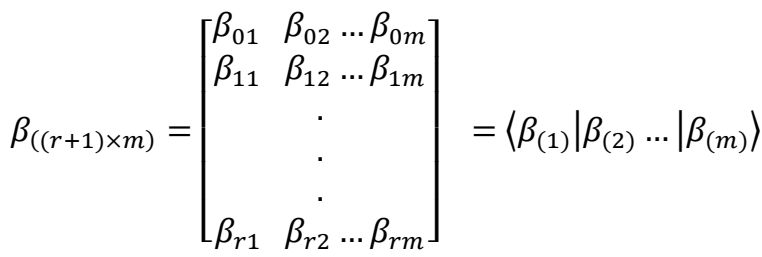




Then multivariate linear regression model is :

$$
\begin{gathered}
Y_{n \times m}=Z_{(n \times(r+1))} \beta_{((r+1) \times)}+\varepsilon_{(n \times m)} \ldots \ldots \ldots \ldots . \\
\text { With } \quad E\left(\varepsilon_{(i)}\right)=0, \operatorname{cov}\left(\varepsilon_{(i)}, \varepsilon_{(k)}\right)=\sigma_{i k} I \\
i, k=1,2, \ldots, \mathrm{m}
\end{gathered}
$$

The $\mathrm{i}^{\text {th }}$ response $Y_{(i)}$ follows the linear regression model

$$
\begin{aligned}
& Y_{(i)}=Z \beta_{(i)}+\varepsilon_{(i)} i=1,2, \ldots m \\
& \text { With } \operatorname{cov}\left(\varepsilon_{(i)}\right)=\sigma_{i i} I .
\end{aligned}
$$

Given the outcomes $Y$ and the values of the predictor variables $Z$ with full column rank, the least squares estimates $\hat{\beta}_{(i)}$ exclusively from the observations, $Y_{(i)}$ on the single - response solution, is given as: $\hat{\beta}_{(i)}=\left(Z^{\prime} Z\right)^{-\prime} Z^{\prime} Y_{(i)}$

\begin{tabular}{|c|c|c|c|c|c|c|c|c|}
\hline \multicolumn{9}{|c|}{ Table 2: Parameter Estimates } \\
\hline \multirow{2}{*}{$\begin{array}{l}\text { Dependent } \\
\text { Variable }\end{array}$} & \multirow[t]{2}{*}{ Parameter } & \multirow[t]{2}{*}{ B } & \multirow[t]{2}{*}{ Std. Error } & \multirow[t]{2}{*}{$\mathrm{t}$} & \multirow[t]{2}{*}{ Sig. } & \multicolumn{2}{|c|}{ 95\% Confidence Interval } & \multirow{2}{*}{$\begin{array}{l}\text { Partial Eta } \\
\text { Squared }\end{array}$} \\
\hline & & & & & & $\begin{array}{l}\text { Lower } \\
\text { Bound }\end{array}$ & Upper Bound & \\
\hline \multirow{4}{*}{ In_GDP } & Intercept & -252.747 & 99.258 & -2.546 & .019 & -459.166 & -46.328 & .236 \\
\hline & In_PMS & 76.577 & 30.085 & 2.545 & .019 & 14.012 & 139.142 & .236 \\
\hline & In_AGO & .211 & .138 & 1.527 & .142 & -.076 & .499 & .100 \\
\hline & In_DPK & .679 & .158 & 4.284 & .000 & .349 & 1.008 & .466 \\
\hline \multirow{4}{*}{ In_reserve } & Intercept & -364.153 & 39.215 & -9.286 & .000 & -445.706 & -282.601 & .804 \\
\hline & In_PMS & 113.578 & 11.886 & 9.556 & .000 & 88.860 & 138.297 & .813 \\
\hline & In_AGO & -.138 & .055 & -2.524 & .020 & -.252 & -.024 & .233 \\
\hline & In_DPK & .074 & .063 & 1.186 & .249 & -.056 & .204 & .063 \\
\hline \multirow{4}{*}{ In_debt } & Intercept & -2156.978 & 350.680 & -6.151 & .000 & -2886.256 & -1427.700 & .643 \\
\hline & In_PMS & 656.614 & 106.289 & 6.178 & .000 & 435.573 & 877.655 & .645 \\
\hline & In_AGO & 1.001 & .489 & 2.046 & .053 & -.016 & 2.018 & .166 \\
\hline & In_DPK & -1.499 & .560 & -2.677 & .014 & -2.663 & -.334 & .254 \\
\hline \multirow{4}{*}{$\begin{array}{l}\text { In_expenditu } \\
\text { re }\end{array}$} & Intercept & 659.636 & 285.867 & 2.307 & .031 & 65.143 & 1254.129 & .202 \\
\hline & In_PMS & -196.787 & 86.645 & -2.271 & .034 & -376.975 & -16.599 & .197 \\
\hline & In_AGO & .739 & .399 & 1.853 & .078 & -.090 & 1.568 & .141 \\
\hline & In_DPK & -.456 & .456 & -.999 & .329 & -1.405 & .493 & .045 \\
\hline \multirow{4}{*}{$\begin{array}{l}\text { In_Per_capit } \\
\text { a_GDP }\end{array}$} & Intercept & -1010.984 & 157.008 & -6.439 & .000 & -1337.501 & -684.468 & .664 \\
\hline & In_PMS & 309.602 & 47.588 & 6.506 & .000 & 210.637 & 408.568 & .668 \\
\hline & In_AGO & -.463 & .219 & -2.113 & .047 & -.918 & -.007 & .175 \\
\hline & In_DPK & .178 & .251 & .712 & .485 & -.343 & .700 & .024 \\
\hline
\end{tabular}

\section{Discusion Of Findings}

Table 1: Descriptive Statistics

\begin{tabular}{|l|r|r|r|}
\hline & \multicolumn{1}{|c|}{ Mean } & Std. Deviation & $\mathrm{N}$ \\
\hline In_GDP & .9286 & .88341 & 25 \\
In_reserve & 10.6812 & .14452 & 25 \\
In_debt & 9.8779 & .56958 & 25 \\
In_expenditure & 10.3719 & .23226 & 25 \\
In_Per_capita_GDP & 10.66 & .323 & 25 \\
\hline
\end{tabular}

The result of the multivariate regression analysis reveals that $\operatorname{lnPMS}$ and $\operatorname{lnDPK}$ have significant effect on lnGDP. The P-value of the intercept being less than 0.05 suggests that an intercept model was appropriate in the univariate model of $\operatorname{lnGDP}$ on $\ln P M S, \ln \mathrm{PPK}$ and $\ln \mathrm{AGO}$. Furthermore, the result shows that a unit increase in lnPMS leads to 76.577 increase in $\ln$ GDP, $\operatorname{lnDPK}$ and $\ln A G O$ remains constant. A unit in $\ln$ AGO increases $\ln$ GDP by 0,211 and a unit increase in $\operatorname{lnDPK}$ increases $\operatorname{lnGDP}$ by 0.679 units.

The univariate model for the lnGDP is:

$\operatorname{lnGDP}=-252.75+76.58 \ln P M S+0.211 \ln \mathrm{AGO}+0.679 \ln \mathrm{nPK}$

Only lnPMS and lnAGO have significant effect on lnreserve. The significance of the intercept suggests that the intercept model is appropriate. A unit increase in lnPMS increases lnreserve by 1.38 units as lnreserve was found to have inverse relationship with $\ln \mathrm{AGO}$. A unit change in $\operatorname{lnDPK}$ leads to 0.074 increase in $\operatorname{lnDPK}$. The univariate model for Inreserve is given as: Inreserve $=-364.15+113.58 \ln P M S-0.38 \ln A G O+0.074 \ln D P K$

A similar case was on served for the lnDEBT as both $\operatorname{lnPMS}$ and $\ln A G O$ have significant impact on external debt. Also an intercept model proved to be an appropriate univariate model. A unit increase in lnPMS 
and $\ln$ AGO brings about 656.6 and a unit increase respectively in $\operatorname{lnDEBT}$, while a unit increase in $\operatorname{lnDPK}$ leads to 1.5 units change in lnDEBT. The univariate model for foreign debt is given as:

lndebt=-2157 + 656.6lnPMS+lnAGO-1.5lnDPK only lnPMS has significant on national expenditure as a unit change in lnPMS leads to 196.79 decrease in The univariate model is given: $\operatorname{lnEXP}=285.87-196.79 \ln P M S$ $+0.739 \ln$ AGO-0.456lnDPK in $\operatorname{lnEXP}$

Similarly, only lnPMS and lnAGO has significant impact on GDP per capita. a unit increase in $\ln A G O$ brings about 0.1463 decrease in lnper_capita_GDP while a unit increase in lnPMS leads to 309.6 units increase in In per capita income the univariate model for per capita GDP and Nigerian economy is given as: ln_per-capita GDP=1011+309.61nPMS-0.463lnAGO+0.1781nDKP

\section{Conclusion}

From the finding, we therefore conclude that PMS has significant impact on all economic variable studied. The AGO has significant impact on only GDP and Per capita GDP while DPK only has significant impact on GDP per capita.

The significance of PMS on all economic variables shows that out of the petroleum products studied, that PMS has the highest impact on the economy. This may be due to the fact that virtually all economic activity such as transportation, electricity generators, and some light machineries solely depend on PMS for optimal functioning. Hence price changes will more shock on both the economy and individuals. The PMS has also been observed to increase the external reserve, service external debt, improve the Nigerian GDN and GDP per capita. The PMS was seen to have inverse relationship with expenditure. This may be attributable to the fact increased prices of PMS do not really reflect on the Nigerians expenditure since most expenditure are made from crude oil earnings.

DPK was found to have negative effect on expenditure as increasing the pump price of DPK will not be good for the Nigerian economy. Similarly, AGO has negative effect on GDP per capita and external reserve, hence increase in the pump price of AGO will not be good for the Nigerian economy.

\section{Recommendation}

From the finding, it is there for recommended that only the removal of PMS subsidy will be good for the Nigerian economy as increase in the price of other products studied will be detrimental to the economy.

\section{Refference:}

[1]. Arinze P. E (2011), "The Impact Of Oil Price On The Nigerian Economy", JORIND (9)1 June, ISSN 1596-8303. www.Transcampus. Org/Journals.

[2]. Ghalayini, L (2011), "The Interaction between Oil Price and Economic Growth" Middle Eastern Finance and Economics, ISSN: 1450-2889 Issue $13 \mathrm{Http}: / / \mathrm{Www}$.Eurojournals.Com/MEFE.Htm

[3]. Onyemaechi J. O, (2012), "Economic Implications Of Petroleum Policies In Nigeria: An Overview", American International Journal Of Contemporary Research Vol. 2 No. 5; May 2012

[4]. Aliyu,S.U. (2009), "Impact Of Oil Price Shock And Exchange Rate Volatility On Economic Growth In Nigeria: An Empirical Investigation”, Associate Professor Of Economics At Bayero University Kano Research Department Of The Central Bank Of Nigeria

[5]. Sharma A, Singh, G and Gupta P, et al (2012), "Impact Of Crude Oil Price On Indian Economy", International Journal Of Social Sciences And Inter Disciplinary Studies. Vol. 1(4), ISSN: 277-3630

[6]. Huang, A.Y, Yi-Heng T, (2010), "Is Crude Oil Price Affected By The US Dollar Exchange Rate?", International Research Journal Of Finance And Economics, ISSN 1450-2887 Issue 58 (2010), Http://Www.Eurojournals.Com/Finance.Htm

[7]. Onwuka E.M, Chiekezie O.M, Igweze, A.H et al (2013) Petroleum Product Prices and the Growth of Nigeria Economy, journal of Business management, DOI: www.theticjour.in/jbne

[8]. $\quad$ Ayadi, O.F. (2005), "Oil Price Fluctuations And The Nigerian Economy”. OPEC Review: 199-217

[9]. Farzanegan, M.R., Markwardt, G., (2009). The Effects of Oil Price Shocks on the Iranian Economy. Energy Economics 31(1), 134-151.

[10]. Olomola, P. A., Adejumo, A.V. (2006). Oil price shock and macroeconomic activity in Nigeria. International Research Journal of Finance and Economics. 3, 28-34.

[11]. Olusegun,O.A. (2008) "Oil Price Shock And Nigerian Economy: A Forecasty Error Decomposition Analysis", Journal Of Economic Theory 2 (4): 124-130, ISSN: 1994-8212

[12]. Etaga H.O. and Igweze, A.H (2011) "Statistical Analysis with Excel, Minitab And SPSS", Tualuas Publishers Asaba.

[13]. Oyeka, C.A (1996) An introduction to applied statistical methods; Nobern Avocation Publishing Company, Enugu.

\section{APPENDIX}

Table 1: data on Petroleum product prices

\begin{tabular}{|c|c|c|c|}
\hline YEAR & Y1 & Y2 & Y3 \\
\hline 1987 & 0.5 & 0.4 & 0.3 \\
\hline 1988 & 0.5 & 0.4 & 0.3 \\
\hline
\end{tabular}


Modelling Petroleum Product Prices And The Nigerian Economy

\begin{tabular}{|c|c|c|c|}
\hline 1989 & 0.6 & 0.5 & 0.4 \\
\hline 1990 & 0.6 & 0.5 & 0.4 \\
\hline 1991 & 0.7 & 0.5 & 0.5 \\
\hline 1992 & 0.7 & 0.55 & 0.5 \\
\hline 1993 & 3.25 & 3 & 2.75 \\
\hline 1994 & 11 & 9 & 6 \\
\hline 1995 & 11 & 9 & 6 \\
\hline 1996 & 11 & 9 & 6 \\
\hline 1997 & 11 & 9 & 6 \\
\hline 1998 & 11 & 9 & 6 \\
\hline 1999 & 20 & 19 & 17 \\
\hline 2000 & 22 & 21 & 17 \\
\hline 2001 & 22 & 21 & 17 \\
\hline 2002 & 26 & 26 & 24 \\
\hline 2003 & 39.5 & 41.5 & 41 \\
\hline 2004 & 48 & 48 & 48 \\
\hline 2005 & 50 & 60 & 50 \\
\hline 2006 & 65 & 60 & 50 \\
\hline 2007 & 65 & 60 & 50 \\
\hline 2008 & 70 & 80 & 70 \\
\hline 2009 & 65 & 110 & 95 \\
\hline 2010 & 65 & 140 & 105 \\
\hline 2011 & 65 & 150 & 105 \\
\hline
\end{tabular}

Key

$\mathrm{Y} 1$

$\mathrm{Y} 2$

Y3
Premium Motor Spirit (PMS)

Automotive Gas Oil (AGO)

Dual Purpose Kerosene (DPK)

Table 2: Economic variables

\begin{tabular}{|c|c|c|c|c|c|}
\hline YEAR & $\mathrm{Z1}$ & $\mathbf{Z 2}$ & $\mathrm{Z3}$ & $\mathbf{Z 4}$ & $\mathrm{Z5}$ \\
\hline 1987 & 27440226402 & 1497832059 & 22211934000 & 22425668244 & 303.66 \\
\hline 1988 & 30156667431 & 932989777 & 29021380000 & 22517976319 & 325.20 \\
\hline 1989 & 32328043288 & 2041078372 & 29621029000 & 22597451628 & 339.82 \\
\hline 1990 & 34977654923 & 4128789621 & 30121999000 & 22046096733 & 358.55 \\
\hline 1991 & 36641050126 & 4678023330 & 33438924000 & 24309383876 & 366.46 \\
\hline 1992 & 37710320429 & 1196052750 & 33527205000 & 25707050695 & 368.10 \\
\hline 1993 & 38539752620 & 1640443739 & 29018714000 & 32141912327 & 367.28 \\
\hline 1994 & 38578292372 & 1649172399 & 30735623000 & 22010154525 & 359.03 \\
\hline 1995 & 39542749682 & 1709113524 & 33092286000 & 23428194338 & 359.43 \\
\hline 1996 & 41243087918 & 4329391830 & 34092471000 & 27517609437 & 366.22 \\
\hline 1997 & 42356651292 & 7781250308 & 31406607000 & 27992162500 & 367.46 \\
\hline 1998 & 43152718562 & 7298545697 & 28454869000 & 33620581711 & 365.75 \\
\hline 1999 & 43627561284 & 5649725440 & 30294495000 & 33603795455 & 361.20 \\
\hline 2000 & 45983449593 & 10099448198 & 29127620000 & 36248792480 & 371.77 \\
\hline 2001 & 47408936530 & 10646598366 & 31354920000 & 35890490302 & 374.17 \\
\hline 2002 & 48143264348 & 7566806238 & 31041588000 & 42861048123 & 370.81 \\
\hline 2003 & 53102020576 & 7415087386 & 30475990000 & 59522437930 & 399.06 \\
\hline 2004 & 58730834757 & 17256543970 & 34617041000 & 66124937296 & 430.58 \\
\hline 2005 & 61902299834 & 28632051719 & 37766889000 & 76518475300 & 442.72 \\
\hline 2006 & 65740242424 & 42735469033 & 22060054000 & 94860449667 & 458.63 \\
\hline 2007 & 69980375057 & 51907034587 & 7693021000 & 124634412481 & 476.21 \\
\hline 2008 & 74179197560 & 53599283557 & 8530680000 & 140899027432 & 492.34 \\
\hline 2009 & 79371741390 & 45509822740 & 11333656000 & 181728255490 & 513.77 \\
\hline 2010 & 85581744176 & 35884925669 & 7713033000 & 154713650842 & 540.21 \\
\hline 2011 & 91293024018 & 36263658533 & 7882519000 & 183714310902 & 561.90 \\
\hline
\end{tabular}

Source: http://data.worldbank.org/country/nigeria 
Key

Z1 GDP 2000 constant USD

Z2 TOTAL RESERVE(USD)

Z3 FGN(EXT DEBT)

Z4 Gross national expenditure at 2000 constant(USD)

Z5 GDP per capita at 2000 constant (USD) 